I Universidade Federal de Pernambco (UFPE), Departamento de Sociologia,

Recife, Pernambuco, Brasil

cynthiahamlin@hotmail.com

https://orcid.org/0000-0002-8370-2192

Cynthia Lins Hamlin'

\title{
GENDER IDEOLOGY: AN ANALYSIS OF ITS DISPUTED MEANINGS ${ }^{1}$
}

Opposition to gender has become a central element in the discourses and initiatives of the "global right". Although the convergence between anti-gender movements and other manifestations of the new right takes distinct and sometimes contradictory forms ${ }^{2}$ (Paternotte \& Kuhar, 20I8; Corrêa, Paternotte \& Kuhar, 20I8), the dismantling of a series of polices for social inclusion and reducing inequalities is at stake. Ideologues of the new right such as Steve Bannon ${ }^{3}$ and Olavo de Carvalho have waged a "culture war" ${ }^{4}$ on enemies like "gender ideology," "globalism" and "cultural Marxism." As Mirrlees (20I8: 49) argues, these epithets act as full-blown "political instruments of intersectional hate" that are applied to values, practices, and identities of a progressive, liberal, or left-wing inclination. They are mobilized and combined in varying forms depending on the type of enemy to be attacked: organizations, parties or specific groups like "communists, blacks, gays, feminists and all those who do not share their mental universe" (Messenberg, 2017: 637).

Much as they prove theoretically and empirically flimsy, many of these counter-narratives are based on the reinterpretation of empirical data, concepts and, more generally, theoretical perspectives developed by academics: "cultural Marxism" is a distortion of the tradition of Western Marxism, especially Gramsci and the first generation of the Frankfurt School; "globalism" is a distortion of the critiques of the economic dimension of globalization, considered an integral part of "cultural Marxism"; "gender ideology" and "gender theory" 
are distortions of feminist and gender theories, in particular queer theory. In this specific sense, we are faced with "projects of alternative knowledge production" (Bracke \& Paternotte, 20I6: I44) or, in more Foucauldian terms, the construction of a new episteme: "a system that produces and organizes knowledge and truth, located strongly in social fields such as religion, education, media and research" (Verloo, 2018: 22).

The academic response has taken the form of genealogies that set out to account for the conditions of emergence of the notion of "gender ideology" utilized by the right, emphasizing religious discourse especially. There is also a considerable literature on how "gender ideology" has become associated with "cultural Marxism," particularly, in the Brazilian context, in the development and political uses of the Escola sem Partido (Non-Party School) program in the area of education (Miguel, 20I6; Junqueira, 20I7; Corrêa, Paternotte \& Kuhar, 2018).

However, in emphasizing the political-moral forces that enabled the emergence of these discourses connected to right-wing populism, most of these analyses do not examine the internal meanings that the concept of gender ideology (without quotation marks) had already acquired within feminist theory itself. While the critique of the uses of the expression as a weapon in the culture war is justified on ethico-political grounds, ignoring the previous history of the sociological concept has the effect of rendering invisible an entire intellectual framework produced by feminist academics, thus contributing, albeit involuntarily, to the process of theoretical-conceptual distortion and/or erasure that grounds the epistemic project of the global right. In fact, much of the literature on the theme of gender ideology - and this is not limited to Brazil - has ignored or denied the existence of the concept in the social sciences, something that has been repeated exhaustively in the media. Only a few works, such as Junqueira (2017: 27), recognize gender ideology as a concept in the social sciences, generally in passing references that fail to explore the tension between the disputed meanings of the phrase. The silence concerning this issue seems unjustified to me. The systematic disqualification of academic discourse is part of a dispute for hegemony that certainly does not suggest a good prognosis for academia if its main strategy consists of accepting that the terms of the debate are based on the systematic distortion and/or erasure of its own concepts.

In this work, I set out to illustrate the plethora of meanings associated with academic discourse on gender ideology and argue that, via distinct though not necessarily competing paths, these meanings converge through a radical negation of the anti-gender discourse of the new right. To this end, I construct my argument in two parts. First, I will map a distinction between, on one hand, a "gender ideology" (in quotation marks) as part of the anti-gender project and, on the other, gender ideology (without quotation marks) as part of the feminist project. This distinction involves a summary of the main arguments developed 
in the genealogical studies concerning the emergence of the "gender ideology" discourse of the global right, followed by a brief explanation of the principal meanings associated with the concept's use in academic research. The second part of the article involves an exercise in the history of ideas ${ }^{5}$ focused on the sociology of Viola Klein, whose analyses of the "ideology of the feminine character" constitute one of the first theoretical explorations of the theme of gender ideology. Klein's work, based on Karl Mannheim's sociology of knowledge elucidates two important questions: firstly, academic studies of gender, from their outset, have been based on a constructivist approach that is profoundly antithetical to the naturalizing and essentializing discourse of the global right; secondly, and no less importantly, gender, as a social construct, is deeply tied to the production of narratives about the meaning of femininity and masculinity. An assessment of Klein's valuable contributions to sociology offers an exemplar of the kind of academic reflections on gender ideology that risk being erased should the social-scientific response to the discourse of the new right be reduced to ignoring the concept as part of the social science lexicon.

\section{"GENDER IDEOLOGY" AND GENDER IDEOLOGY: DISPUTED MEANINGS}

The recent literature on "gender ideology" has emphasized the use of the expression as opposition to and rejection of the concept of gender through a series of discussions surrounding women's reproductive health, sexual education, recognition of the identity of trans persons, same-sex marriage, or adoption by non-heterosexual couples (Miskolci \& Campana, 20I7; Cornejo-Valle \& Pichardo, 2017). Although these works emphasize the fact that the Catholic Church does not have a monopoly on this opposition, it is not only considered one of its main protagonists, sometimes it is also identified as responsible for inventing the term gender ideology (Bracke \& Patternote, 20I6; Case, 20I6). These works also specify that opposition to gender became more visible as a response to its use in mainstream policies proposed at the United Nations Conference in Cairo, I994, and in Beijing, I995, when the term "woman," used in the previous conferences, was substituted by the term "gender." This substitution met with resistance among the coalition of diverse religious actors attending the conferences: the Vatican, the US Christian right, and a diverse group of Christian-and Islamic-majority states (Butler, 2004). The terminological variability of the opposition to gender has also been explored in recent investigations of the theme: "gender ideology," in the contexts of Latin America, Africa, and some European countries (like Poland and Italy), transforms into "gender theory" in the French context (Fassin, 20I6; Garbagnoli, 20I6) and occasionally too in the Brazil of Minister Damares Alves.

Beyond their differences, these discourses operate by reducing gender to (binary) sex through a simplified and distorted representation of biology itself: "since religion's capacity to justify gender ideology collapsed, biology has 
been called in to fill the gap" (Connell, 2005: 46). Hence, the religious discourse of the Catholic Church became modernized through an anthropology of complementarity according to which human beings are conceived as biologically sexed and the sexes as essentially different (biological dualism), "though not unequal" (Case, 2016: I55). Difference was distinguished from inequality through a kind of anti-colonialism that, read more closely, reveals itself to be a form of opposition to international organizations like the UN, UNESCO, the OECD, and others that have developed gender equality policies. A speech by Pope Francis in Poland on World Youth Day, July I6, 20I6, clearly illustrates this strategy:

In Europe, America, Latin America, Africa, and in some countries of Asia, there are genuine forms of ideological colonization taking place. And one of these - I will call it clearly by its name - is [the ideology of] gender. Today children - children! - are taught in school that everyone can choose his or her sex. Why are they teaching this? Because the books are provided by the persons and institutions that give you money. These forms of ideological colonization are also supported by influential countries. And this [is] terrible! [...] In a conversation with Pope Benedict [...] he said to me: 'Holiness, this is the age of sin against God the Creator.' God created man and woman; God created the world in a certain way... and we are doing the exact opposite. God gave us things in a 'raw' state, so that we could shape a culture; and then with this culture, we are shaping things that bring us back to the 'raw' state! (quoted in Bracke \& Paternotte, 2016: 143).

Although the Vatican's theological anthropology indicates some compatibility with the liberal idea of reducing inequalities in opportunities, an idea that guides international organizations like those cited, what is offered by one hand is violently taken away by the other when the Church suggests that inclusion policies are forms of ideological colonization. In fact, the religious use of academic jargon not only establishes a distinction between nature and culture in which the former takes a primary role; more fundamentally, what is in question are the diverse forms of social constructivism.

It is precisely under the guise of constructivism, understood in the broad sense of a form of anti-essentialism and anti-reductionism, that the studies of gender ideology developed in the social sciences can be understood. Since their earliest formulations, these studies have emphasized the socially constructed dimension of the meanings of femininity and masculinity. As occurs in the anti-gender discourse, studies of gender ideology also present an ample terminological variation: ${ }^{6}$ gender ideology, sexual role ideology, gender role ideology, attitudes about gender, attitudes relating to gender, gender equality, and beliefs about gender are expressions that have been used with a similar meaning in a series of research studies in areas like sociology, anthropology, psychology, administration, literary studies and so on (Davis \& Greenstein, 2009). The use of one term over another is generally due to conceptual distinctions within the field,7 but Kroska (2007: I867-I868) summarizes the issue adroitly: 
Both gender ideology and gender role ideology refer to attitudes regarding the appropriate roles, rights, and responsibilities of women and men in society. The concept can reflect these attitudes generally or in a specific domain, such as an economic, familial, legal, political, and/or social domain. Most gender ideology constructs are unidimensional and range from traditional, conservative, or anti-feminist to egalitarian, liberal, or feminist. [...] Gender ideology also sometimes refers to widespread societal beliefs that legitimate gender inequality. [...] Used in this way, gender ideology is not a variable that ranges from conservative to liberal; instead, it refers to specific types of beliefs - those that support gender stratification.

The differences highlighted by Kroska reflect the polysemy of the concept of ideology itself. The use of the term in the social sciences can involve everything from sophisticated theoretical models to the simple identification of a set of shared ideas about a particular theme. ${ }^{8}$ In sum, the concept of ideology has been given two main meanings over its more than 200 years of history: a critical, negative or prescriptive meaning, "used to evaluate a state of affairs" through association with ideas like inversion, distortion, mystification, false consciousness, reification, alienation, illusion, misrepresentation, bias, domination, interpellation and subjectivation; and a descriptive or neutral meaning whereby "ideologies can be regarded as 'systems of thought,' 'systems of belief' or 'symbolic systems' which pertain to social action or social practice" (Thompson, 2000: I4). From a theoretical viewpoint, the negative or prescriptive conception of ideology is associated primarily with the work of Marx and Engels (though it may involve readings deeply critical of their humanism, as found among 'post-Marxists' such as Zizek and Laclau); ${ }^{9}$ while the descriptive or neutral conception is found especially in the work of Karl Mannheim (see note I2).

The form in which the expression gender ideology is used in academic studies depends, therefore, on the conception of ideology adopted. However, it is important to note that, in practice, the separation sustained by Kroska is not always maintained: it is possible to identify authors who use both conceptions of ideology when they refer to gender ideology. Furthermore, some studies can clearly be characterized as studies on gender ideology - i.e., studies that focus specifically on the identification, classification, or understanding of these ideologies - while others merely refer to the term in order to integrate the ideological dimension with other analytic themes and domains of social life.

One of the main focal points of studies on gender ideology is the measurement of "individuals' levels of support for a division of paid work and family responsibilities that is based on the belief in gendered separate spheres" (Davis \& Greenstein, 2009: 87). These tend to be descriptive studies of individual beliefs and practices relating to the division of paid and unpaid work. Many of these studies are presented in the form of attitude scales or large surveys in which theory plays a minor role - examples being the General Social Survey 
linked to the United States Census, the World Values Survey, and surveys like those developed by the International Social Survey Program. As Kroska emphasizes, this type of survey tends to work with one-dimensional conceptions of gender ideology. Recent research, though, has argued in favor of multivariate approaches that transcend the developmentalist premise expressed in the traditional/modern divide. Grunow, Begall and Buchler (2018), for example, in a comparative study of eight European countries, construct distinct clusters through the identification and differential combination of five profiles that potentially coexist in different domains of social life: egalitarian, essentialist egalitarian, intensive parental care, moderate traditional and traditional (see too Araújo \& Scalon, 2006).

Studies on gender ideology can also take a historical and critical approach, as in the case of Besse (I999), who describes the reconfiguration of Brazilian patriarchy in the Vargas Era (I930-I945) through an ideological analysis of the gender system in the family, education, the labor market, and politics. Gender ideology appears in these domains as a way of reconciling the demands of modernization and economic development with the stability of existing power relations.

Studies of gender ideology have been particularly impactful in the sociology of work. An example is the classic text The second shift by Hochschild and Machung (2003) in which the authors break with the quantitative emphasis characteristic of most attitude scales by replacing closed questionnaires with participant observation and interviews. Their aim is to understand the "emotional work" involved in the interpersonal tensions between couples in economic contexts marked by rapid change. The comprehension of this emotional work involves the identification and negotiation of "traditional," "egalitarian" or "transitional" gender ideologies among couples, as well as the conflicts present in the division of labor. The starting point of the research, characteristic of the first formulations of the concept in general, is that the influx of women into the paid labor market has not been accompanied by cultural changes regarding the meaning of marriage and work itself.

Hochschild and Machung's work is located at the interface of what I call studies on gender ideology and studies that make use of the notion of gender ideology to integrate the theme of ideology with diverse analytical topics and perspectives. Many other research studies linked to the sociology of work make similar use of the notion of gender ideology, whether in relation to domestic work or "in the production system [which] orient distinct management practices" (Heilborn \& Sorj, I999: I9-20).

This latter use of the concept of gender ideology is by far the most widespread in the feminist and gender literature, and, as in the preceding case, may alternate between both meanings of ideology. By way of illustration, - and excluding here its correlates like "ideology of femininity," "ideology of masculin- 
ity" or "patriarchal ideology" -, the term appears in analytic topics and perspectives as distinct as Saffioti (2009: 26 and ff), Longino (I993: I02 and ff), De Lauretis (I987, Chapter I) and Collins (I990: I83 and ff). An endless multiplicity of such examples exist, but Raewyn Connell provides a good summation of what is involved:

In Gender and power [Connell, 2003], I have a chapter called "Sexual ideology" (which would have been better called "Gender ideology"). Looking at it now, I think the chapter oscillates between the two meanings in a potentially confusing way. In Gender: in world perspective [Connell \& Pearse, 20I5] I tried to solve such ambiguities, and integrate the cultural analysis better into the structural analysis, by defining culture/symbolism/communication as one of the four substructures of gender. This, in effect, generalizes the "neutral" version of ideology, which is treated as a terrain of social practice on which political struggles occur. The critical analysis becomes a second layer of analysis, when we see cultural formations such as fashion, theology, sport, pop music and school curricula as bearers of gendered interests resulting from structural inequality. [...] the feminist and social-scientific literature shows both the critical and the neutral usage of "ideology" when it treats gender. In my work they sometimes intermingle (e.g. chapter II of Gender and power), and sometimes move towards one or the other pole. (E.g. my discussion of hegemonic masculinity rests on a critical theory of ideology, derived ultimately from Gramsci and Lukács.) I think you would be right to say that I'm not a "gender ideology" researcher. But you would have to say that I have tried to integrate the problem of ideology into an approach to gender that also gives weight to material interests, economies, states, violence and sexuality. The point (I think) is that good ideology-critique never stands alone (personal communication via email. Reproduced with the author's permission).

Even in cases where the analysis of gender ideology is not the sole or the primary aim of the research, therefore, it may constitute an important aspect of the examination of the cultural dimension of gender relations in society. Use of the term varies from case to case - for instance, adhering to a theoretical framework inspired by Lukács, Saffioti uses a critical conception of the term; De Lauretis also works with its critical meaning, but from a perspective rooted in Althusser; Collins oscillates between a critical meaning associated with the work of authors like Franz Fanon and Paulo Freire, and a more descriptive meaning. ${ }^{\text {Io }}$

Having demonstrated the diffusion of the term in the humanities, as well as the plethora of meanings associated with its use, I now turn to the work of Viola Klein to illustrate how its meanings in the sociology of knowledge prompt a series of questions that ultimately lead to conceiving of gender itself as a social construct. Viola Klein's pioneering work focuses particularly on the relation between knowledge and the social production of gender, albeit not always in a consistent fashion.

\section{THE SOCIOLOGY OF KNOWLEDGE AND THE IDEOLOGY OF THE FEMININE CHARACTER}

Viola Klein (I908-I973) belongs to a generation of intellectuals whose work was published between the I940s and the beginning of the I960s - thus between the first and second wave of feminism. Less well known than some of her contempo- 
raries, such as Margaret Mead, Simone de Beauvoir and Mirra Komarovsky, Klein shared with them and others of their generation themes like the malleability of the human personality, the social construction of femininity, and the ideological justifications that reinforce women's position of subordination (Tirrant, 2006). In Klein's case, these themes, fundamental to the later development of the concept of gender, also involved another form of constructivism that was epistemological in kind.

Born in Vienna during the Austro-Hungarian Empire, Klein came from a politically progressive Jewish family in which women's independence was encouraged. In I928, she spent a year studying at the Sorbonne before heading to the University of Vienna and later moving to Czechoslovakia with her family. After four years working as editor at a newspaper, she studied French, Spanish, philosophy, and psychology (including psychoanalysis), obtaining her first doctorate at the University of Prague in French literature in I937. Although Klein was already interested in the "woman question" - she published articles on marriage and on the persistence of prostitution in the Soviet Union - the topic of her first thesis was the work of Louis-Ferdinand Céline, known for his direct prose, closer to the working classes, and for his antisemitic positions (Tirrant, 2006; Lyon, 2007). Klein's analysis of the "the social nature of linguistic constructions and usage addressed in her thesis, and the ways in which oppressive lived realities become ideologically constructed in opportunistic political and scientific discourse" (Lyon, 2007: 83I) are still pertinent and relevant, and profoundly marked her intellectual trajectory. It was also through the research involved in this thesis that she came across Karl Mannheim's work. In I939, shortly before the German invasion of Prague, Klein and her brother fled to England where she worked as a housemaid for about two years before obtaining a scholarship from the Czech government in exile to study social sciences at the London School of Economics. In I94I, she met Mannheim, also exiled in London after the rise of $\mathrm{Na-}$ zism, with the idea of a project on women's emancipation (Lyon, 2007).

Since the I930s, while still at the University of Frankfurt, Mannheim had already considered the situation of women to be an important theme, supervising various female doctoral students. In I932, in a speech addressed to Dutch students, Mannheim (I993) makes this importance clear when he argues that class cannot be considered the only social group capable of selfconsciousness and rational transformation of the world. For him, the impulse towards self-consciousness has been present throughout history and arose from contact with alterity or the perspective of an Other. In this sense, selfconsciousness cannot be reduced to a class perspective but includes other groups, like intellectuals, women, or young people. In sum, groups that found themselves in a crisis due to the discrepancy between their objective social situation and the conceptions through which they framed their actions, lead- 
ing towards self-knowledge and towards the critique of the kind of knowledge produced about them. This was translated to the plane of women in the following form:

We see everywhere (although in variable degrees and in different forms) woman becoming more conscious of her own being. She has begun to reflect about herself. Undoubtedly, she was not the first to do so: everybody knew what woman was, as her partner, or rather her opponent, imagining how they would like her to be. The striking fact is that man occupied the dominant position and could express his thoughts, while woman lacked a consciousness of her own, and accepted his thoughts about her as binding truth, both in her spiritual life and in her everyday action (Mannheim, I993: 73).

While emphasizing his debt to the theory of knowledge present in Marx's work, Mannheim introduced a far more pluralistic perspective by stressing that our interpretation of the world invariably stems from belonging to distinct groups. In an important sense, Mannheim contributed decisively to identifying forms of injustice that are irreducible to questions of economic redistribution. From an epistemological perspective, his sociology of knowledge also proclaimed the importance of the researcher's self-consciousness in relation to their localization for, only then, setting out from this personal experience in the world, can they establish the critical distance necessary to sociology: "those who have not yet despaired of their own situation cannot truly enter sociology and should abandon it" (Mannheim, quoted in Gianoncelli, 20I6: 49). This reflection not only explains his pioneering interest in a sociology of women, but also reveals the intimate relations that he established between knowledge and politics, a concern deepened after his arrival in England. In this new phase of his work, sociology's objective was no longer simply to counter heteronomous factors that obscure self-consciousness and individual autonomy, but to promote mobilization and social planning (Kettler \& Meja, I993) - revealing an intense preoccupation with the formation of a welfare state that, by safeguarding individual freedoms, would oppose "conservative historicism, bourgeois liberalism, socialism and communism, [and] fascism” (Villas Bôas, 2002: I27).

Beyond the interest in women, Klein shared with Mannheim a culture that valued the idea of Reason present in the Enlightenment (in the sense of Bildung, or formation/education), a multidisciplinary approach to social questions, the interest in art and literature, and support to social democratic movements (Lyon, 2007). Although he believed that she could equally have chosen antisemitism as a research topic, even recommending that she read a project coordinated by Max Horkheimer at Columbia University (Kettler \& Meja, I993), Mannheim agreed to supervise what would become her second doctoral thesis. Completed in 1944 under the title Feminism and anti-feminism: a study in ideologies and social attitudes, the thesis was subsequently published in 1946 with a new title suggested by Mannheim: The feminine character: history of an ideology. 
Klein's proposed research question was to know "whether there are traits which can be called typically feminine, what these traits are, and whether they have always been regarded as characteristic of women" (Klein, I972: I). She believed that, given its emotional resonance, the theme was particularly suited to demonstrating the influence of unconscious and irrational factors on scientific theories. Considering scientific knowledge to be situated within a broader "cultural system," she concluded that the theories produced about women reflect three main elements: the status of women in each society, the ideologies relating to women in a given historical period, and the personal attitudes of researchers in relation to women. These three elements were integrated into her analysis of the "feminine character" II in biology (Havellock Ellis), philosophy (Otto Weiniger), psychoanalysis (Freud), experimental psychology (Helen Thompson), psychometry (L. M. Terman and C. C. Miles), history (Mathilde Vaerting), anthropology (Margaret Mead) and sociology (W.I. Thomas).

From a theoretical standpoint, Klein began with the incompatibility between the "objective situation of women," who were beginning to participate in the public sphere in large numbers, and the perspectives that were supposed to inform their actions, which still emphasized an ideology of domesticity. Limiting her analysis to middle and upper-middle class women, based on the premise that working class women were never outside the paid labor market, Klein explains this objective situation through factors like shrinking family size, the creation of a compulsory school system, and greater attention to education in general, as well as an increase in the number of women in the paid labor market before marriage. This situation created a dilemma at the psychological level, resulting from the contrast between changes in the material dimension without something comparable occurring at the ideological level. Thus, women from her generation were guided by two incompatible ideologies: one emphasizing "the quality of rights and capacities," the other emphasizing traditional roles linked to the domestic sphere: "The characteristic feminine conflict of our time is that put forward by the domestic sphere on the one side, and the business sphere on the other" (Klein, I972: 33).

But it is in scientific knowledge production that Klein would seek the traces of these ideologies and conclude that, in different degrees and emphases, theories concerning the "feminine character" are heavily influenced by an ideology of domesticity that emphasizes traits like "passivity, emotionality, lack of abstract interests, greater intensity of personal relationships, and an instinctive tenderness for babies" (Klein, I972: I64).

From a methodological viewpoint, her thesis adopts Mannheim's "integrative method," combining different aspects of the same problem according to how it was treated by authors who studied the topic within a particular period: 
'Truth' in social matters presents itself in terms of various 'perspectives.' By the method of a Sociology of Knowledge these 'perspectives' are exposed to criticism and, as time goes on, an ever richer 'integration sui generis' of these aspects becomes possible by an ever fuller understanding of their partiality. Relativism is thereby avoided, and a theory of 'Relationism' established which takes into account the fact that knowledge of social matters is connected with the social and cultural background (Klein, I972: 3).

Additionally, although Klein provides no explicit link to the type of "socioanalysis" that she undertook, the conception of knowledge underlying her doctoral thesis echoed her supervisor's concerns:

The search for truth in sociological matters calls not only for a thorough examination of the facts, but for a dynamic process of self-criticism, in which the diagnosis of our own 'perspective' (i.e. our place in the historical and social process) and a continuous analysis of the unconscious motivations guiding our observations are of prime importance (Klein, 1972: 3).

Inspired perhaps by this kind of reflection, Klein did not limit herself to simply revealing the ideological dimension of the theories about the feminine character in her own time, but included a socio-psychological premise that also anticipates questions connected to what we today understand as processes of subjectivation: women, as well as

foreigners, Jews, Negroes, etc. [...] are subject to collective judgements instead of being treated on their own merits. [...] To be judged, not as an individual but as a member of a stereotyped group, implies an incalculable amount of restrictions, discouragement, ill-feelings - even if the occasional flattering generalization may help to bolster up a weakening ego (Klein, I972: 4-5).

Nowhere in her thesis does Klein define the concept of ideology, but there are indications that she subscribes to Mannheim's dual conception: ${ }^{12}$ as well as making use of the concept to refer to systems or worldviews - especially political ones (when she refers, for instance, to "democratic ideology" or "liberal ideology") -, ideology also appears as a synonym for stereotypes associated with psychological feelings, as in a later publication:

[A]lthough there is no uniform feminine 'type,' society carries, as part of its ideological baggage, a stereotype of Woman, a sort of rough model purporting to contain the essential characteristics, while all the existential features are but variations on a basic theme. Stereotypes - defined by Kimball Young as false classificatory concepts to which, as a rule, some strong emotional-feeling tone of like or dislike, approval or disapproval, is attached - are popular means to simplify, indeed to oversimplify, a complex social reality (Klein, I950: 3, emphasis in original).

Thus, given the impossibility of revealing the nature of the feminine character through Mannheim's integrative method, Klein deepens her supervisor's belief that the construction of a welfare state cannot be the magical re- 
sponse to all problems. ${ }^{\mathrm{I} 3}$ In her analysis of Margaret Mead's work, for example, she points to the dangers of social planning (Klein, I972: I36), which can be used "to produce uniformity, rigid control, a short-termed and one-sided efficiency, and endless monotony and frustration." For her - in a way that is surprising given the context in which her work was produced, namely the development of policies focused on women -, the antidote to totalitarianism was to reject "the standardization of two sex temperaments as two 'clearly contrasting, complementary, antithetical' personality types” (Klein, I972: 6), as well as the danger of the universalization of a male perspective.

Incidentally, Klein's pioneering research anticipated what became central preoccupations of contemporary feminist social epistemology. Indeed, she made many contributions. She was not alone in this endeavor, of course. Margaret Mead, Mirra Komarovsky and Simone de Beauvoir, to mention just some figures of her generation, helped combat the reductionism and essentialism that dominated intellectual production about women. In applying the sociology of knowledge to gender, Klein raises questions still relevant today concerning the relationship between the contexts of production of sexual ideologies, their subjectivizing effects, and their consequences for the gender domain.

I am not questioning whether the language of roles or the use of the concept of ideology are the best ways to explore concepts such as binarism, essentialism or the universalism/particularism relation that constitute some of Klein's principal contributions to feminist and gender theories that followed in her wake. Everything indicates that they are not, especially if we consider that the affinity of her thought with so-called "liberal feminism" does not allow those questions to be further investigated - something that would require a much more radical critique of the inequalities inherent to capitalism, as well as of heterosexuality as an exclusive or dominant cultural standard. Nevertheless, two important aspects should be noted: first that, despite the difficulties linked to the concept of ideology, what Mannheim designated by the term can be identified today by other sociological concepts such as "social constructivism" or even "discourse analysis" (Kumar, 2006) - as in the aforementioned work of De Lauretis (1987) and Laclau (2014). Second, as Raewyn Connell argues, it is possible to develop "the sociology of knowledge to raise questions about the contexts of the production of sexual ideology, its consequences for the gender order, and the social character of its producers" (Connell, 2003: n.p.). Klein's work on the scientific discourses of her era represents an excellent example of both.

\section{CONCLUSION}

The term gender ideology cannot be reduced to the anti-intellectual or antiacademic meaning preached by the global right, a meaning that has been the subject of a series of excellent genealogical analyses by social scientists. Prior to its transformation into a weapon of the "culture war," the term had been 
used in feminist and gender studies to target those very ideas that inform the political project of the global right. Despite this fact, we need to recognize that the movements linked to the global right share an important element with academia: a narrative structure, in other words a discourse, centered on thinking about thought. In this specific sense, it amounts to a narrative about epistemology - that is, about the production of what counts as knowledge and truth. But there are substantial differences. In a context marked by the supposed disappearance of shared minimum standards of objectivity and truth, an important element in the epistemic project of the global right is the systematic assault on teaching, research and media institutions and others linked to cultural production. This constitutes a very particular gesture of what philosophers, historians and sociologists of science have characterized as "agnotology": the social production of ignorance based on the erasure, forgetting or distortion of certain forms of knowledge, frequently for economic and/or political ends (Proctor, 2008). This, in sum, is what the discourses on "cultural Marxism," "globalism" and "gender ideology" are all about.

These epistemological narratives are deeply linked to producing doubt and disbelief in established sources of knowledge and information. In this specific sense, ignorance is not simply the opposite of knowledge, the vacuum that precedes it, the lack of knowledge derived from focusing interest somewhere else, or, as we can learn from Klein's work, a perspectivism associated with the researcher's social position. Ignorance here is the result of an active construction, a strategic maneuver with the objective of relativizing or even denying positions well-established by the academic and scientific community by blocking information, by creating disinformation or, purely and simply, by lying (Kourany, 20I8). This kind of strategy marked the concept of gender after the United Nations conferences in I994 and I995, which began to be conceived through a notion of ideology that amounts to a mere term of abuse (see note 8).

Thus, the central point of my argument is that the silence of social scientists in relation to the sociological use of gender ideology as a category whether by limiting their analyses to the meaning used by conservative movements, or by explicitly denying that this is a category used by the social sciences - has non-trivial consequences. Following the anthropophagic logic of capitalism, terms like "ideology," "gender" and "colonization" - to limit myself to those used by Pope Francis - have been appropriated by movements of the global right. If one of the focal areas of contemporary feminist studies consists of making visible the production of women, this strategy contributes precisely to erasing female authors who helped pave the way for the type of knowledge that today allows us, among other things, to question the sexual politics of the global right.

Clearly, this does not imply a theoretical or even political concordance with the development of an academic literature about gender ideology. What 
is at stake is something much more basic: free thought as an antidote to antiintellectualism and dogmatism. In a period when academic freedom finds itself under constant threat, it is essential that we do not allow our discourses to be hijacked by groups and organizations that confuse objectivity with censure or who turn their political views into a moral foundation that justifies "the fear of thinking, indeed, the fear of the question" (Butler, 2004: I80). Accepting this would not only amount to excluding from our concerns the freedom of academic thought and discourse, but would also preclude the very possibility of scrutinizing the historical processes that made their silencing possible.

Received on 29/7/2019 | Revised on 29/5/2020 | Approved on 30/6/2020

Cynthia Lins Hamlin is professor in the Department of Sociology at UFPE, where she coordinates the Study Group in Social Theory (GETSS/PPGS). Research interests in social theory, social science methodology, and feminist theory and epistemology. Her recent publications include articles such as "Consumindo como uma garota" (with Gabriel Peters), and "An exchange between Gadamer and Glenn Gould on hermeneutics and music", as well as book chapters like "Peter Berger (I929-20I7)", "Realismo crítico", and an entry on Raymond Boudon Blackwell Encyclopedia of Sociology. 


\section{NOTES}

I Versions of this paper have benefitted from the criticisms and suggestions of a large number of people, including Betânia Ávila, Frédéric Vandenberghe, Fuyuki Kurasawa, Gabriel Cohn, Márcia Couto, Ricardo Antunes, Silke Weber, and Simone Brito, as well as members of the Study Group in Social Theory and Subjectivities at PPGS/UFPE. Special thanks to Raewyn Connell for the exchange of emails that helped me elucidate her work considerably. Finally, I also express my gratitude to the anonymous reviewers of Sociologia \& Antropologia.

2 In Holland, for instance, far-right parties have demonstrated a very particular and paradoxical form of opposing gender as part of anti-immigration policy. Parties like the PVV and the PvD maintain that gender equality is a fundamental Dutch value at risk of disappearing due to the recent "Islamization" of Europe. At the same time, these parties have been characterized by a strong parliamentary opposition to any measures designed to reduce gender inequalities. In other words, they are "for gender equality but against measures to ensure gender equality" (Verloo, 2018: 25).

3 For an excellent analysis of the ideological program of Steve Bannon, former adviser to Donald Trump's campaign who elected Eduardo Bolsonaro (son of Brazilian president Jair Bolsonaro) as the main representative of his populist army in Latin America (the Neo-Nationalist International), see the essay by Jeffrey Alexander (2018). Under the suggestive title "Raging against the Enlightenment," the author explains not only the bellical nature of Bannon's project but also its profoundly anti-Enlightenment meaning.

4 Although the notion of "culture war" was never used by Gramsci himself, the term has been used in reference to his political theory, which, very briefly, addresses the possibility of building a communist society in the West through democratic means: in place of revolution, the articulation, on the cultural dimension, of a series of values, ideas and traditions that ensure the "intellectual and moral direction" of particular groups not through force but through the creation of a consensus (Gramsci, 20I I: 290). In Brazil, appropriating Gramsci's political concepts, Olavo de Carvalho in- 
verts the Gramscian position by proposing a counter-hegemonic project to "cultural Marxism," "globalism" and "gender ideology."

5 Obviously an exhaustive history of ideas in relation to the concept of gender ideology is beyond the scope of this paper. My choice of the term appears simply as an alternative to the Foucauldian term "genealogy", insofar as Klein's work is treated here as one of the "origins" of the concept in the social sciences.

6 To illustrate this variety, in a brief compilation of the abstracts published in Sociological Abstracts between 2000 and 2008, Davis and Greenstein (2009: 89) identified I68 articles dedicated to discussing levels of individual support for the division of paid and unpaid work by gender: 75 articles out of this total used the terminology "attitudes related to gender roles," 53 referred to "gender ideology," 24 mentioned "gender attitudes" or "attitudes relating to gender" and the rest were divided among terms like "beliefs concerning gender," "attitudes on gender" and "gender equality."

7 See, for example, the feminist debate surrounding the concept of sexual roles in mainstream sociology and its gradual substitution by the concept of gender in Englishspeaking countries (Lopata \& Thorne, I978, Connell, I979; Komarovsky, I992). Put succinctly, criticism focus on the functionalist roots of the concept of roles, its over-proximity to biology, its difficulty in handling social change and power relations, and, more generally, its focus on inter-individual relations rather than the structural dimensions of social life.

8 Everyday use of the term ideology basically tends to imply ideas that contrast with facts. As Terry Eagleton (2004: n.p.) wrote apropos the anti-philosophical and anti-academic pragmatism of modern politicians: "As with bad breath, ideology is always what the other person has. Socialism and anti-racism are ideas; greed and inequality are just plain, honest-to-goodness facts of life."

9 Briefly, what the poststructuralist tradition rejects is the idea that the analysis of ideology enables the unveiling or unconcealing of a fundamental truth and, in this sense, 
that ideology involves a false or distorted discourse in opposition to a true discourse. The ideological critique present in discourse analysis appears above all in terms of the forms through which discourses are constructed as self-contained identities, how particular contents present themselves as universal, and the subjectivizing effects of these processes. It is in this sense that, in authors like Laclau (2014), the category "ideology" loses its epistemological status and takes on an eminently political character. My thanks to Leonardo Almeida for this insight.

Io For an analysis of the epistemological dimension associated with use of the term gender ideology by Hill Collins, see Hamlin \& Peters (2018).

II In her foreword to the second edition of The feminine character, Klein (I972: xviii) recognizes that the phrase "feminine character" was substituted by those of sexual roles and gender roles - in her view, phrases more adequate to underlining the recognition that humans beings are not just biological organisms but "organisms in social situations."

I2 Mannheim (I936) makes a distinction between a "particular" or "psychological" conception of ideology and a "total" or "epistemological" conception. Roughly speaking, the former refers to the classification of an adversary's ideas as a function of the relationship between their psychological interests and their political and/or socioeconomic interests, while the latter refers to the relationship between a sociohistorical group and its frameworks for interpreting the world, allowing comprehension of an opponent's particular perspective through their group belonging. It is on the basis of this distinction that the concept of ideology acquires a descriptive or classificatory dimension, which will become a topic of criticism by a series of authors, notably those linked to critical theory such as Adorno and Horkheimer. For these authors, by abdicating the dialectical dimension of the concept, Mannheim had flirted with positivism, making the concept of ideology lose its critical edge. For an excellent overview of this critique, see the article by Glaucia Villas Bôas (2002).

I3 Klein's efforts to contribute to the development of a welfare state appear especially in her works from the I950s with Alva Myrdal. 


\section{BIBLIOGAPHY}

Alexander, Jeffrey. (2018). Vociferando contra o Iluminismo: a ideologia de Steve Bannon. Sociologia \& Antropologia, 8/3, p. I009-1023.

Araújo, Clara \& Scalon, Celi. (2006). Gênero e a distância entre a intenção e o gesto. Revista Brasileira de Ciências Sociais, 2I/6, p. 45-68.

Besse, Susan K. (I999). Modernizando a desigualdade: reestruturação da ideologia de gênero no Brasil, I9I4-I940. São Paulo: Edusp.

Bracke, Sarah \& Paternotte, David. (2016). Unpacking the sin of gender. Religion \& Gender, 6/2, p. I43-I54.

Butler, Judith. (2004). Undoing gender. New York: Routledge. Case, Mary Anne. (2016). The role of the popes in the invention of complementarity and the Vatican's anathematization of gender. Religion \& Gender, 6/2, p. I55-I72.

Collins, Patricia H. (I990). Black feminist thought: knowledge, consciousness, and the politics of empowerment. London: HarperCollins Academic.

Connell, Raewyn. (2005) [1995]. Masculinities. Berkeley: University of California Press.

Connell, Raewyn. (2003) [1987]. Gender and power. Cambridge/Oxford: Polity Press. [e-book]

Connell, Raewyn. (1979). The concept of role and what to do with it. Australian and New Zealand Journal of Sociology, I5/3, p. 7-I7.

Connell, Raewyn \& Pearse, Rebecca. (20I5). Gênero: uma perspectiva global. São Paulo: nVersos.

Cornejo-Valle, Mónica \& Pichardo, J. Ignacio. (2017). La "Ideología de Género" frente a los derechos sexuales y reproductivos: el escenario espanol. Cadernos Pagu, 50. Available at <http://www.scielo.br/pdf/cpa/n50/r809-4449cpa-I8094449201700500009.pdf>. Accessed 20/Feb./20I9. Corrêa, Sonia; Paternotte, David \& Kuhar, Roman. (2018). The globalisation of anti-gender campaigns. International Politics and Society. Available at <https://www.ips-journal. eu/topics/human-rights/article/show/the-globalisation-of-anti-gender-campaigns-276I/>. Accessed 20/Feb./20I9. 
Davis, Shannon \& Greenstein, Theodore. (2009). Gender ideology: components, predictors and consequences. Annual Review of Sociology, 35, p. 87-105.

De Lauretis, Teresa. (1987). Technologies of gender: essays on theory, film and fiction. Bloomington/Indianapolis: Indiana University Press.

Eagleton, Terry. (2004). Why ideas no longer matter. The Guardian. Available at: <https://www.theguardian.com/ books/2004/mar/23/immigrationpolicy.politics $>$. Accessed Io/Feb./2020).

Fassin, Éric. (2016). Gender and the problem of universals: catholic mobilizations and sexual democracy in France. Religion \& Gender, 6/2, p. I73-186.

Gabargnolli, Sarah. (2016). Against the heresy of immanence: Vatican's "gender" as a new rhetorical device against the denaturalisation of the sexual order. Religion \& Gender, 6/2, p. I87-204.

Gianoncelli, Eve. (2016). La subjectivation en pratique: le devenir féministe de Viola Klein entre experience de l'alterité et sociologie de la connaissance. Cahiers du Genre, 6I, p. 49-72.

Gramsci, Antonio. (20II). Hegemonia, guerra de movimento, guerra de posição. In: Coutinho, Carlos Nelson. O leitor de Gramsci. Rio de Janeiro: Civilização Brasileira, p. 290-300. Grunow, Daniela; Begall, Katia \& Buchler, Sandra. (2018). Gender ideologies in Europe: a multidimensional framework. Journal of Marriage and Family, 80, p. 42-60.

Hamlin, Cynthia \& Peters, Gabriel. (2018). Consumindo como uma garota: subjetivação e empoderamento na publicidade voltada para mulheres. Lua Nova, I03, p. 167-202. Available at: <https://www.scielo.br/scielo.php?pid=Soro 2-644520I8000I00I67\&script $=$ sci_abstract\&tlng=pt $>$. Ac cessed 20/Feb./20I9.

Heilborn, Maria Luiza \& Sorj, Bila. (I999). Estudos de gênero no Brasil. In: Miceli, Sérgio. O que ler na ciência social brasileira (I970-I995). São Paulo: Editora Sumaré/Anpocs/ Capes, p. I83-22I.

Hochschild, Arlie R. \& Machung Anne. (2003). The second shift. London: Penguin. 
Junqueira, Rogério. (20I7). 'Ideologia de Gênero': a gênese de uma categoria política reacionária - ou: A promoção dos direitos humanos se tornou uma 'ameaça à família natural'?. In: Ribeiro, Paula R. C. \& Magalhães, Joanalira. Debates contemporâneos sobre educação para a sexualidade. Rio Grande: Ed. da Furg, p. 25-52.

Kettler, David \& Meja, Volker. (I993). Their "own peculiar way": Karl Mannheim and the rise of women. International Sociology, 8/I, p. 5-55.

Klein, Viola. (I972) [1946]. The feminine character: history of an ideology. London: Routledge \& Kegan Paul.

Klein, Viola. (1950). The stereotype of femininity. Journal of Social Issues, 7/3, p. 3-I2.

Komarovsky, Mirra. (I992). The concept of social role revisited. Gender \& Society, 6/2, p. 30I-313.

Kourany, Janet A. (20I8). Agnotology, feminism and philosophy: potentially the closest of allies. In: Garavaso, Pierana. The Bloomsbury companion to analytic feminism. New York: Bloomsbury Academic.

Kroska, Amy. (2007). Gender ideology and gender role ideology. In: Ritzer, George. The Blackwell Encyclopedia of Sociology. Malden/Oxford: Blackwell Publishing.

Kumar, Krishan. (2006). Ideology and sociology: reflections on Karl Mannheim's ideology and utopia. Journal of Political Ideologies, II/2, p. I69-I8I.

Laclau, Ernesto. (20I4). The rhetorical foundations of society. London: Verso.

Longino, Helen. (1993). Subjects, power and knowledge: description and prescription in feminist philosophies of science. In: Alcoff, Linda \& Potter, Elizabeth. Feminist epistemologies. New York/London: Routledge.

Lopata, Helena \& Thorne, Barrie. (1978). On the term "sex roles". Signs: Journal of Women in Culture and Society, 3, p. 7I8-72I.

Lyon, E. Stina. (2007). Viola Klein: forgotten émigré intellectual, public sociologist and advocate of women. Sociology, 4I/I5, p. 829-842.

Mannheim, Karl. (I993). The sociology of intellectuals. Theory, Culture and Society, io, p. 69-80. 
Mannheim, Karl. (1936). Ideology and utopia: an introduction to the sociology of knowledge. London: Routledge \& Kegan Paul.

Messenberg, Debora. (2017). A direita que saiu do armário. Sociedade e Estado, 32/3, p. 62I-647.

Miguel, Luis Felipe. (20I6). Da "Doutrinação Marxista" à "Ideologia de Gênero": Escola sem Partido e as Leis da Mordaça no Parlamento brasileiro. Direito e Práxis, 7/I5, p. 590$62 \mathrm{I}$.

Mikolsci, Richard \& Campana, Maximiliano. (20I7). "Ideologia de gênero": notas para a genealogia de um pânico moral contemporâneo. Revista Sociedade e Estado, 32/3, p. 723-745.

Mirrlees, Tanner. (2018). The alt-right's discourse of "Cultural Marxism": a political instrument of intersectional hate. Atlantis Journal, 39/I, p. 49-69.

Paternotte, David \& Kuhar, Roman. (20I8). Disentangling and locating the "Global Right": anti-gender campaigns in Europe. Politics and Governance, 6/3, p. 6-19.

Proctor, Robert N. (2008). Agnotology: a missing term to describe the cultural production of ignorance (and its study). In: Proctor, Robert N. \& Schiebinger, Londa. Agnotology: the making and unmaking of ignorance. Stanford: Stanford University Press.

Saffioti, Heleieth. (2009). Ontogênese e filogênese do gênero: ordem patriarcal de gênero e a violência masculina contra mulheres. Flacso Brasil, p. I-44 (Série Estudos e Ensaios/Ciências Sociais).

Thompson, John B. (2000). Ideologia e cultura moderna: teoria social crítica na era dos meios de comunicação de massa. Petrópolis: Vozes.

Tirrant, Shira. (2006). When sex became gender. London: Routledge.

Verloo, Mieke. (2018). Gender knowledge, and opposition to the feminist project: extreme-right populist parties in the Netherlands. Politics and Governance, 6/3, p. 20-30.

Villas Bôas, Glaucia. (2002). Os portadores da síntese: sobre a recepção de Karl Mannheim. Cadernos CERU, 2/I3, p. I 25-I 43 . 


\section{IDEOLOGIA DE GÊNERO: UMA ANÁLISE DOS SENTIDOS EM DISPUTA}

Resumo

O discurso sobre "ideologia de gênero" como "arma de guerra cultural" vem sendo analisado em uma série de estudos genealógicos relativos aos processos históricos recentes que possibilitaram sua emergência. Como esses estudos mostram, trata-se de um projeto alternativo de produção do que conta como conhecimento e como verdade. Contudo, pouca ou nenhuma atenção vem sendo dada aos sentidos que a expressão assume nas teorias feministas e de gênero. Ao negar que a ideologia de gênero pode ser reduzida a um mero espantalho produzido pela agenda conservadora, proponho uma espécie de história das ideias associadas à expressão, com ênfase no trabalho da socióloga Viola Klein, cujas reflexões em sociologia do conhecimento constituem uma das primeiras explorações teóricas do tema. Ao ilustrar a pluralidade de sentidos dos estudos acadêmicos sobre ideologia de gênero, argumento que, embora por vias distintas, eles convergem numa negação radical do discurso antigênero da direita global.

\section{GENDER IDEOLOGY: AN ANALYSIS OF ITS DISPUTED MEANINGS}

In the last few years, a number of genealogical studies have been published about recent historical processes that enabled the emergence of the discourse on "gender ideology" as a "weapon in the culture war." As some of these studies suggest, what is at stake is an alternative project of knowledge and truth production. Little or no attention, however, has been given to the meanings of gender ideology internal to feminist and gender theories. Rejecting the idea that gender ideology can be reduced to a straw man produced by a conservative agenda, I propose a brief history of ideas associated with the concept, foregrounding the work of sociologist Viola Klein, whose reflections on the sociology of knowledge represent one of the first academic investigations of gender ideology. In illustrating the plethora of meanings associated with the concept, I argue that they converge towards a radical negation of the anti-gender discourse of the global right.

\section{Palavras-chave}

Ideologia de gênero;

direita global;

sociologia do conhecimento;

Viola Klein;

agnotologia.

\section{Keywords}

Gender ideology;

global right; sociology of knowledge;

Viola Klein;

agnotology. 